\title{
Evaluation of ambient air quality in Dehradun city during 2011-2014
}

\author{
Amar Deep ${ }^{1}$, Chhavi P Pandey ${ }^{2, *}$, Hemwati Nandan ${ }^{3}$, K D Purohit ${ }^{1}$, \\ Narendra Singh ${ }^{4}$, Jaydeep Singh ${ }^{4}$, A K Srivastava ${ }^{5}$ and Narendra Ojha ${ }^{6}$ \\ ${ }^{1}$ Department of Physics, HN B Garhwal University, Srinagar, Garhwal 246 174, India. \\ ${ }^{2}$ Wadia Institute of Himalayan Geology, Dehradun 248001 , India. \\ ${ }^{3}$ Department of Physics, Gurukula Kangri Vishwavidyalaya, Haridwar 249 404, India. \\ ${ }^{4}$ Aryabhatta Research Institute of Observational Sciences, Manora Peak, Nainital 263 129, India. \\ ${ }^{5}$ Indian Institute of Tropical Meteorology, Prof Ramnath Vij Marg, New Delhi 110 060, India. \\ ${ }^{6}$ Department of Physics, Graphic Era University, Dehradun 248 002, India. \\ *Corresponding author. e-mail: chhavi@wihg.res.in
}

MS received 1 September 2017; revised 25 June 2018; accepted 3 July 2018; published online 2 April 2019

The variations in the ambient concentrations of particulate matter $\left(\mathrm{SPM}\right.$ and $\left.\mathrm{PM}_{10}\right)$ and gaseous pollutants $\left(\mathrm{SO}_{2}\right.$ and $\left.\mathrm{NO}_{2}\right)$ at Clock tower (CT), Rajpur road (RR) and Inter State Bus Terminal (ISBT) station in Dehradun city, Uttarakhand, India are analysed for the period of 2011-2014. Mean concentrations are observed to be higher during pre-monsoon season as compared to the winter and monsoon. $\mathrm{PM}_{10}$ and SPM concentrations with maximum values of $203 \pm 23$ and $429 \pm 49 \mu \mathrm{g} \mathrm{m}^{-3}$, respectively, during winter, are found to exceed the national standards by factors of 2 and 3 . Winter-time elevated pollution in Dehradun is attributed to the lower ventilation coefficient (derived from Era interim model fields) and minimal precipitation. Nevertheless, the $\mathrm{SO}_{2}$ and $\mathrm{NO}_{2}$ levels are observed to be within the criteria notified by the Central Pollution Control Board (CPCB), India. Correlation analysis shows profound impacts of the meteorology and local dynamics on the observed variations in observed trace species. Additionally, the stronger inter-species correlation variations $\left(r=0.79\right.$ for $\mathrm{SO}_{2}$ with $\mathrm{NO}_{2}$, and $r=0.89$ for $\mathrm{PM}_{10}$ with SPM), which may suggest their origin from common sources. Analysis of 'Air Quality Index (AQI)' variations indicates unhealthy atmospheric conditions near the major city centers and bus station. More observations in the region are highly desirable to understand the dispersion of the enhanced pollution in the Dehradun valley.

Keywords. Air pollutants; statistical analysis; meteorological parameters; air quality index.

\section{Introduction}

Deleterious changes in atmospheric composition due to the introduction of contaminants are referred as the air pollution. The concentration of air pollutants depends not only on the quantities that are emitted from different emission sources but also on the subsequent chemical and dynamical processes in the atmosphere. In fact, a thick blanket of pollution traps heat around the earth and therefore, plays a significant role in global warming and climate change (Ramanathan and Feng 2009). Presently, air pollution is deteriorating rapidly over much of the globe during past few decades (e.g., Akimoto 2003). Change in the regional vegetation cover, land use and many 
developmental activities are increasingly affecting the local air quality as well as the weather patterns. A number of studies have reported the variations in criteria pollutants over mega cities in India (Aneja et al. 2001; Gurjar et al. 2008). With an increasing level of urban population (Sokhi and Kitwiroon 2008; UN-Habitat 2012), adverse environmental impacts (Wenzel et al. 2007; Gurjar et al. 2010) pose a serious threat to human health globally (Ravindra et al. 2016). Large consumption of fossil and bio-fuels are contributing to the alarming levels of pollutants especially in the megacities (Butler et al. 2008; Ravindra et al. 2016), and the outflux of the pollutant plumes (Molina and Molina 2004; Kanakidou et al. 2011) from the mega cities affects the environment at regional and global scales with associated political and potential socio-economic impacts (Krass 2007; Gurjar et al. 2016). In particular, some earlier investigations (Chauhan and Joshi 2008; Chauhan et al. 2010), concerning about the regional zone (Dehradun and adjacent locations) realized that transport vehicles and industrial emission are the major sources of air pollutants in this region. These investigations also revealed that the gaseous pollutants in this expanse generally are always well within the Indian air quality standards while the concentration of particulate matter exceeds the criteria (Chauhan and Joshi 2010; Awasthi et al. 2016; Deep et al. 2017). According to a recent report of World Health Organization (WHO) released in 2016, Dehradun is the 15th most polluted city in India; however, it is 31st most polluted city in the world. The report by WHO is based on the amount of fine particulate matter, i.e., $\mathrm{PM}_{2.5}$ present in the air in a particular region. Once considered a green city, the inclusion of Dehradun in the list of the most polluted cities in the world is alarming and is anticipated to affect the air quality and climate in the region.

In order to have a continuous monitoring of air quality in India, the Government of India has enacted the AIR (Prevention and Control of Pollution) Act in 1981 and the Environment (Protection) Act in 1986. The Central Pollution Control Board (CPCB) under the AIR (Prevention and Control of Pollution) Act initiated a national ambient air quality monitoring system in the year 1986 to collect the air pollution data with a wide network of monitoring stations throughout the country (CPCB 2003, 2012, 2015). There is also a national meteorological service in India namely the India Meteorological Department (IMD) which was established in 1875 to take meteorological observations with an aim to conduct and promote the research in meteorology, seismology and other allied subjects in the country. Since the issues related to air quality, weather and climate, vegetation and human health are closely interrelated therefore, the air pollution data and meteorological data collected by CPCB and IMD, respectively, provide a database for research with diverse scientific objectives. Apart from the influence of local emissions, air pollutants can get transported from sources at distant regions to the Himalayan foothills (e.g., Solanki et al. 2013; Sarangi et al. 2014; Srivastava et al. 2014; Ojha et al. 2017). It is usually detected with remote sensing devices such as Lidar, and such events are quite common during summer and forming the elevated layers in the lower troposphere, which finally settles down in the foothill of Himalayas and might contribute to the local sources at occasions, and leading to sudden rise in the levels of particulate pollutants.

In the present paper, we analyze the variations in ambient air quality of Dehradun city in Uttarakhand during 2011 period utilizing CPCB observations and meteorological data from IMD in Dehradun. The organization of this paper is as follows. A brief description of the study sites and local meteorology is presented in sections 2.1 and 2.2. A detailed statistical analysis of air pollutants is performed in section 3 followed by the results and discussion (section 3). A summary and conclusions are presented in the section 4 .

\section{Material and methodology}

\subsection{Description of study sites}

Dehradun $\left(30^{\circ} 19^{\prime} \mathrm{N}, 78^{\circ} 04^{\prime} \mathrm{E}, 410-600\right.$ amsl), the capital city of Uttarakhand state of India, is located in a valley in southwestern part of Uttarakhand. In fact, Himalayas on its north and Shiwalik on the south provides it the shape of a valley. After its inception as the capital city of Uttarakhand, the environmental conditions worsen gradually, mainly due to the increasing number of anthropogenic activities. The major causes of anthropogenic environmental pollution in the city are industrialization, deforestation, urbanization, large-scale construction, unplanned development, rapid population growth, and increasing number of vehicles, etc. As per census 2011, population of Dehradun increased by more than $30 \%$ as 


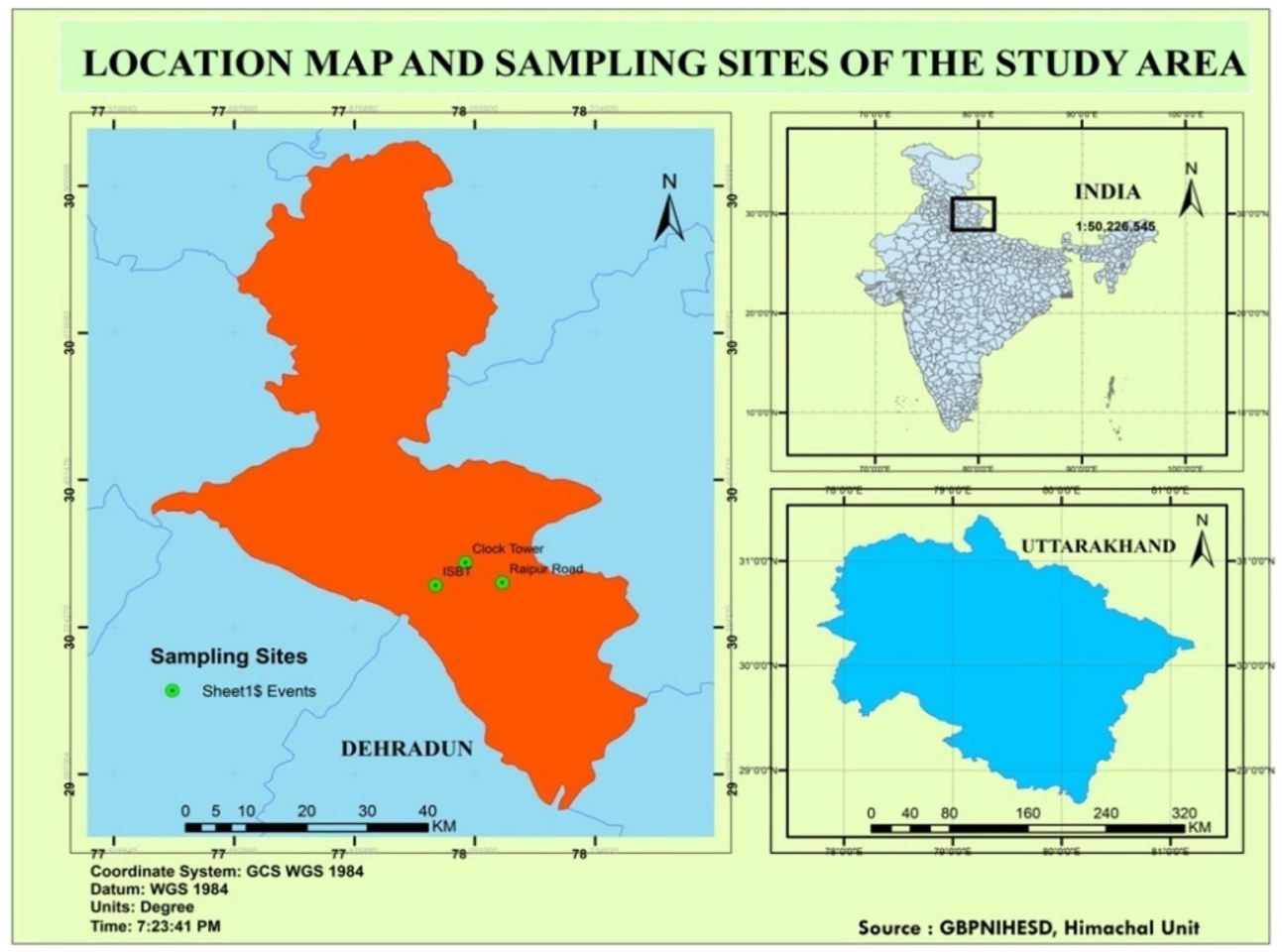

Figure 1. Location of the study sites in Dehradun city of Uttarakhand state, India.

compared to that during 2000. In order to study the air quality in Dehradun, we have selected three different sites as shown in figure 1. These three different sites with highest expected pollution levels are Clock tower (CT), Rajpur road (RR) and Inter-State Bus Terminal (ISBT).

\subsection{Observations of pollutants and local meteorological parameters}

Particulate matter (PM) consists of a mixture of solid and liquid particles suspended in the air (NAAQMS 2009). Suspended particles with aerodynamic diameter of less than $10 \mu \mathrm{m}$ are commonly known as $\mathrm{PM}_{10}$ and particles with diameter less than $2.5 \mu \mathrm{m}$ are however known as $\mathrm{PM}_{2.5}$ or respirable suspended particulate matter (RSPM). The major gaseous pollutants include sulfur dioxide $\left(\mathrm{SO}_{2}\right)$, nitrogen dioxide $\left(\mathrm{NO}_{2}\right)$, carbon monoxide $(\mathrm{CO})$ and ozone $\left(\mathrm{O}_{3}\right)$. The dominant source of insertion of above mentioned pollutants in the atmosphere is fossil fuels and can be anthropogenic as well as natural. Meteorological conditions also play an important role and further determine the fate of the air pollutants after subsumed into the atmosphere.

The climate of the region is classified under humid sub-tropical type. The summers in Dehradun are moderately hot while the winters are very cold.
The temperature may rise up to about $41^{\circ} \mathrm{C}$ in summers, though the average temperature remains around $35-36^{\circ} \mathrm{C}$. There are about $1-2$ days of heat waves when the maximum temperature of a day rises to $4-6^{\circ} \mathrm{C}$ above the normal values. Though, the winters are not bitterly cold on most of the days, the temperatures may however fall to $1-2^{\circ} \mathrm{C}$ for a few days in winters when the cold winds from the nearby Himalayan mountains makes the winters severe. The winters in Dehradun are also marked by mist and fog on few days especially during nights and early in the mornings. Dehradun is one of the rainiest capital cities of India. Due to altitudinal variations and local topography, the rainfall and temperature variations within the city are quite considerable. Especially during the past two decades, landscape of the city has changed drastically and deforestation at very fast pace changes its microclimate. Figure 2 depicts the observed variations in rainfall $(\mathrm{mm})$, maximum temperature $\left({ }^{\circ} \mathrm{C}\right)$ and relative humidity $(\%)$ in Dehradun during the study period. The highest rainfall observed on is in the months of July and August, whereas the highest temperatures are observed in the month of May every year. Humidity during all seasons is almost above $30 \%$ and most of the time about $90 \%$ during monsoon months.

Figure 3 shows the seasonal variability in the wind speed and wind direction over Dehradun. 


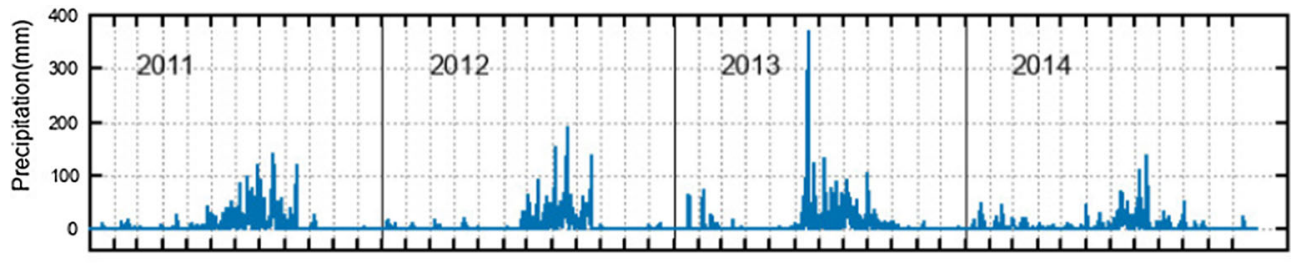

JFMAM J JASONDJFMAMJJASONDJFMAMJ JASONDJFMAMJJASOND
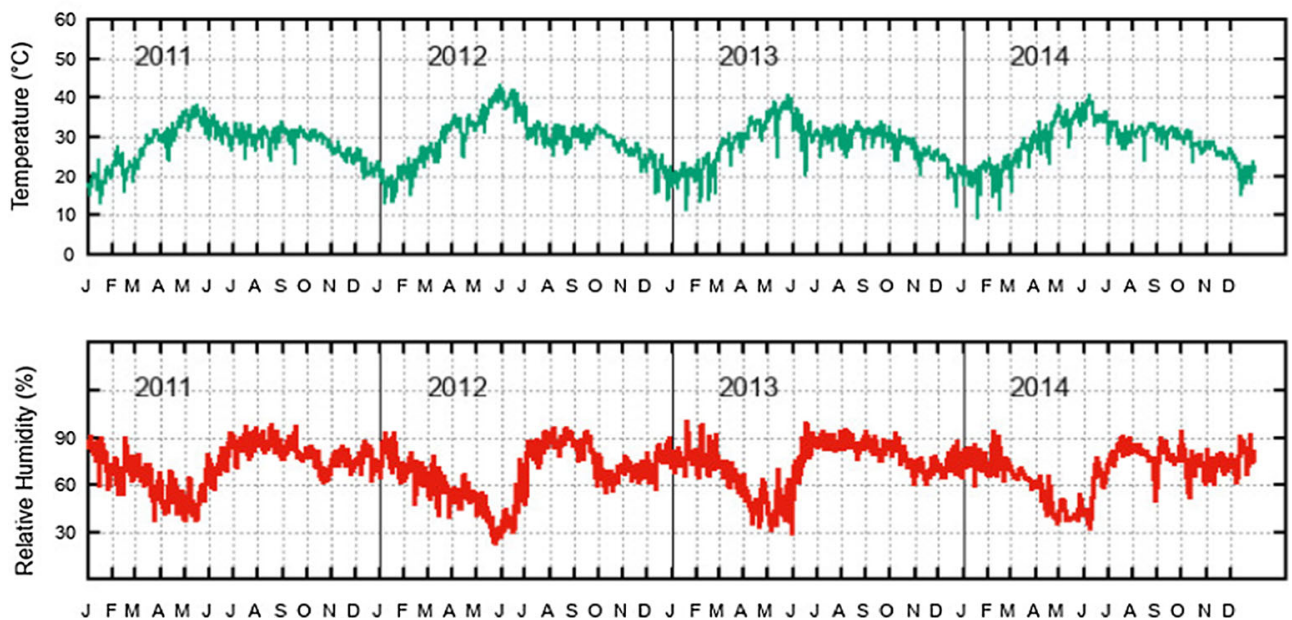

Figure 2. Variations in local meteorological parameters at Dehradun: precipitation $(\mathrm{mm})$, temperature $\left({ }^{\circ} \mathrm{C}\right)$ and relative humidity (\%) during the study period (i.e., 2011-2014).

2012

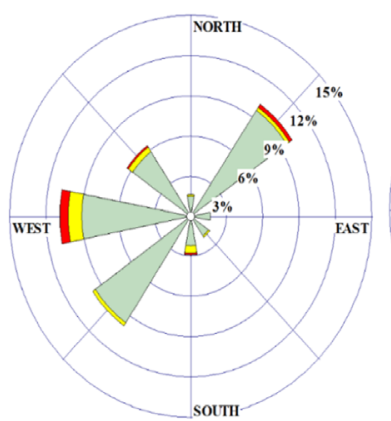

(a) Winter

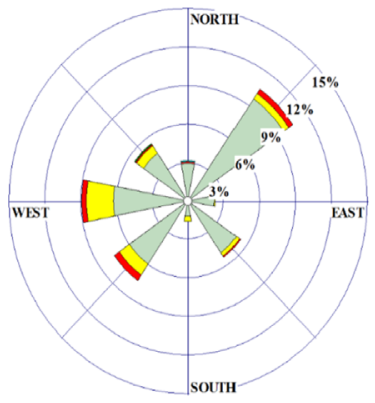

(c) Monsoon

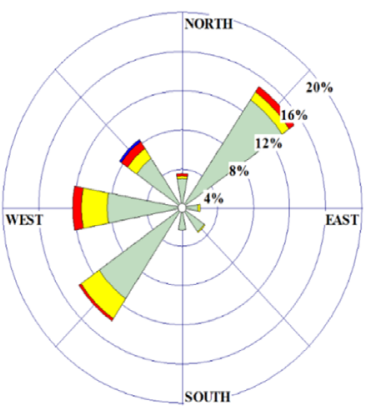

(b) Pre-Monsoon

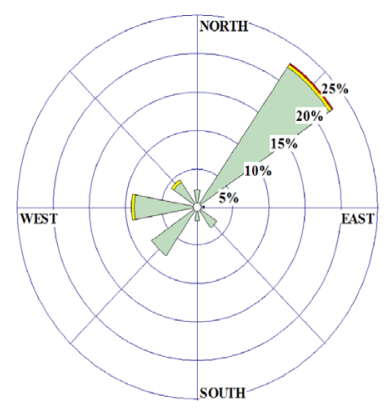

(d) Post-Mon soon

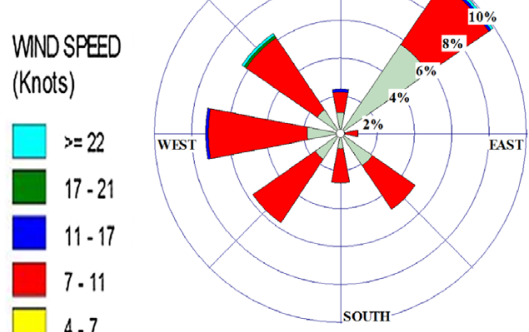

(a) Winter

Cams: $53.92 \%$

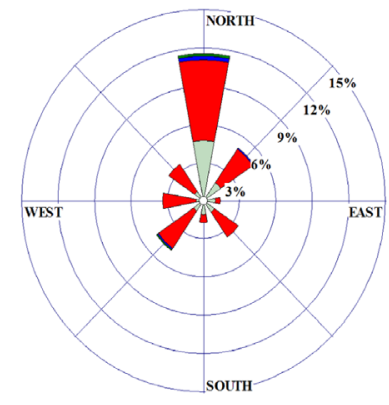

(c) Monsoon
2013

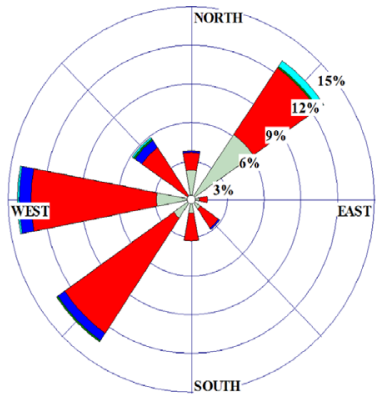

(b) Pre-Monsoon

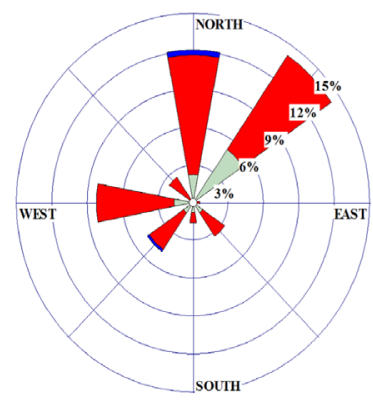

(d) Post-Mon soon

Figure 3. Variations in wind speed and direction over Dehradun for different seasons during 2012 and 2013.

Pre-monsoon and monsoon seasons are typically dominated by south westerlies and westerlies, with the magnitude between 0.5 and $3.5 \mathrm{~m} \mathrm{~s}^{-1}$. However, a branch of north-easterly $\left(0.5-2.5 \mathrm{~ms}^{-1}\right)$ is observed to prevail throughout the year. During pre-monsoon and winter, the transport from west 
and north-west could enhance the pollution over to the Himalayan foothills and up to some extent over Dehradun.

\subsection{Instrumentation and data analysis}

The variations in the ambient concentrations of $\mathrm{SO}_{2}, \mathrm{NO}_{2}, \mathrm{PM}_{10}$ and $\mathrm{SPM}$ in Dehradun as measured by the CPCB for a period of four years 2011-2014 are analyzed. The measurements were carried out at three locations of the city as discussed in section 2.1.

The collection of the data of air pollutants was done with the help of a Respirable Dust Sampler (RDS) Envirotech (460) NL. This dust sampler was used to monitor particulate matter below $10 \mu \mathrm{m}\left(\mathrm{PM}_{10}\right)$ under ambient air quality monitoring, based on filtration-gravimetric method using a Whatman filter paper $(20.3 \times 25.4 \mathrm{~cm})$. The apparatus was kept at a height of $2 \mathrm{~m}$ above the ground level. The concentration of SPM and $\mathrm{PM}_{10}$ were determined using high efficiency filter paper method by passing air at high flow rate, which retains the particles. The gaseous pollutants such as sulphur dioxide $\left(\mathrm{SO}_{2}\right)$ and nitrogen dioxide $\left(\mathrm{NO}_{2}\right)$ were also monitored simultaneously in an attached impinger with the dust sampler. $\mathrm{NO}_{2}$ and $\mathrm{SO}_{2}$ were collected by bubbling in a specific absorbing solution (sodium hydroxide for $\mathrm{NO}_{2}$ and sodium tetra-chloromercuate for $\mathrm{SO}_{2}$ ) at an average flow rate of $0.1-0.5 \mathrm{~min}^{-1}$. The collected samples were then placed in iceboxes immediately after sampling and afterwards kept in a refrigerator prior to their analysis. Finally, all the samples were analyzed in the laboratory by CPCB. Modified methods of West and Gaeke (1956) and Jacobs and Hochheiser (1958) were followed for the analysis of different gaseous pollutants. However, there are also errors (instrumental and human) associated with the measurements and the sample analysis. The measurements are performed under the controlled conditions. The dataset of gaseous pollutants was collected four times during each day, while the dataset of particulate matter was acquired thrice in a day. This collection of data was performed from 6 am to $6 \mathrm{pm}$ every day. The meteorological datasets were obtained from IMD (http://amssdelhi.gov.in/ Nigam/MCDDN/). Using these datasets, in the present study, we have calculated the correlation between different meteorological parameters and the air pollutants. Seasonal cycle of the meteorological variables such as wind speed, mixing depth, and ventilation coefficient, is generated from ERA-interim reanalysis datasets (http://apps.ecm wf.int/datasets/data/interim-full-daily/levtype $=\mathrm{sf}$ c/) provided by the European Center for Medium Range Weather Forecasts (ECMWF) and utilized to understand the possible association with pollution dynamics over the region.

\section{Results and discussion}

Available datasets are subjected to statistical analysis and a monthly mean is obtained to understand the seasonal and year-to-year variations in pollutant concentrations in Dehradun as discussed in the sections.

\subsection{Temporal variation of the pollutants}

The variations in monthly average concentrations of the measured pollutants during 2011-2014 periods are shown in figure 4 . The levels of pollutants are found to be minimum, in general, during monsoon months. However, as compared to the period 2011-2013, during 2014 the mean levels are relatively higher. In the year 2014, reductions in $\mathrm{NO}_{2}$ and $\mathrm{SO}_{2}$ during monsoon time are smaller, while larger effects were observed in previous three years (2011-2013). Monsoon is basically a variable synoptic scale phenomenon and possesses significant inter-annual variability, hence may contribute to such reductions from one year to the other. Weaker monsoon means, bringing less rain, and thus reducing the scavenging of the pollutants from atmosphere, which may result into the relatively larger concentrations of $\mathrm{NO}_{2}$ and $\mathrm{SO}_{2}$, in the year 2014, as compared to the previous years. SPM and $\mathrm{PM}_{10}$ also show similar trends. However, they show maxima during spring and summer for all three sites. Monthly mean values of $\mathrm{SO}_{2}$ and $\mathrm{NO}_{2}$ further show a gradual increase from 2011 to 2014. In the year 2011, the highest levels of $\mathrm{SO}_{2}$ were in the range of $25-30 \mu \mathrm{g} \mathrm{m}^{-3}$ during winter and summer, whereas the mean values approached $30 \mu \mathrm{g} \mathrm{m}^{-3}$ and remain above $25 \mu \mathrm{g} \mathrm{m}^{-3}$ throughout 2011-2014. The higher levels during winter time are attributed to the lower boundary layer heights confining the pollutants in to a shallower volume during winter. Similarly, the mean concentrations of $\mathrm{PM}_{10}$ indicate gradual increase and ranging between 200 and $300 \mu \mathrm{g} \mathrm{m}^{-3}$; however, the highest values are observed in the month of May 2012. For SPM, the highest values $\left(687 \mu \mathrm{gm}^{-3}\right)$ 

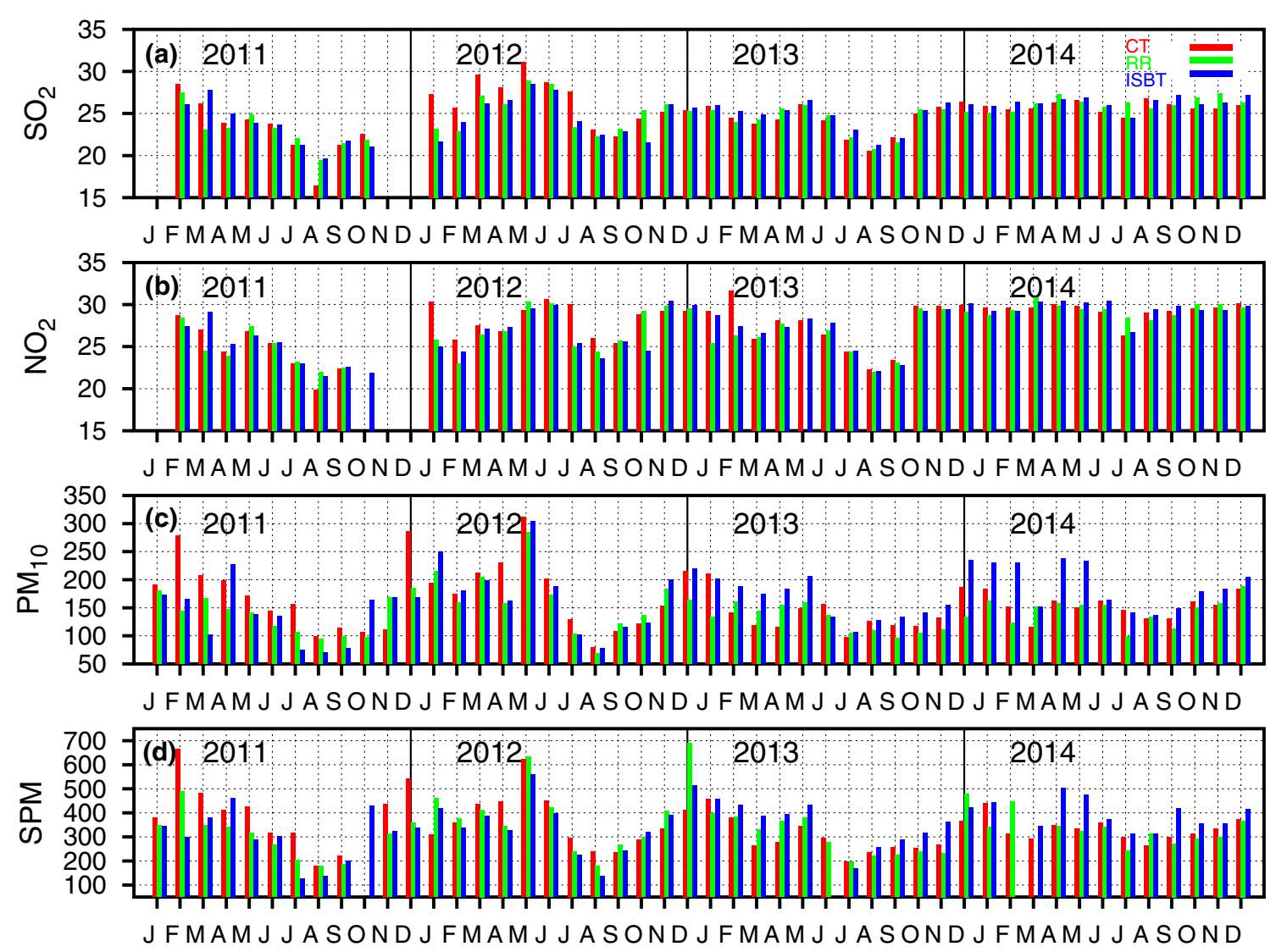

Figure 4. Variations in the monthly average concentrations of $\mathrm{SO}_{2}, \mathrm{NO}_{2}, \mathrm{PM}_{10}$ and $\mathrm{SPM}$ in Dehradun during $2011-2014$.

are observed in the month of December 2012. Seasonal variations in wind speed, mixing depth and ventilation coefficient obtained from ECMWF ERA-interim-forecasts are used with $3 \mathrm{hr}$ resolution and shown in figure 5 during the study period. Meteorological field data was obtained with $\sim 13 \mathrm{~km}\left(0.125^{\circ} \times 0.125^{\circ}\right)$ of interpolation grid. Average mixing depth is seen to be highest during pre-monsoon, while it is lower during the summer monsoon (in August) and winter (in January). Lack of rain combined with lower ventilation is suggested to be driving the observed winter time maxima in Dehradun. Variations in other meteorological parameters as well as in the emissions also contribute to the observed variations (Ojha et al. 2012; Dumka et al. 2017; Tiwari et al. 2017 and references therein).

\subsection{Inter-seasonal and inter-annual variability of air pollutants}

In order to study the seasonal variations of the pollutants, the analysis at various time scales is carried out based on the prevailing meteorological conditions over the year using standard classification of IMD. It classifies the meteorological seasons over India as: winter (January-February), pre-monsoon (March-May), southwest monsoon (June-September) and post-monsoon (OctoberDecember) (IMD 2015). The seasonal variation of particulate matter and gaseous pollutants are presented in figure $6(\mathrm{a}-\mathrm{d})$ and the respective statistics as mentioned in table 1 , which indicate that at the three study sites, there are significant seasonal variations in the concentrations of gaseous and particulate pollutant. $\mathrm{PM}_{10}$ levels were observed to be highest during winter season, except in the year 2012 where it was maximum in the pre-monsoon. In the year 2011, the highest seasonal average of $162 \mu \mathrm{g} \mathrm{m}^{-3}$ was recorded in the winter while lowest $\left(99 \mu \mathrm{g} \mathrm{m}^{-3}\right)$ were observed in the monsoon. However, in the year 2012, the maximum $192 \mu \mathrm{g} \mathrm{m}^{-3}$ was recorded in the pre-monsoon and the lowest $127 \mu \mathrm{g} \mathrm{m}^{-3}$ in the monsoon. In the year 2013, highest $156 \mu \mathrm{g} \mathrm{m}^{-3}$ was recorded in the winter season and lowest $115 \mu \mathrm{g} \mathrm{m}^{-3}$ in the monsoon season. In the year 2014, the corresponding highest and lowest values were 154 and $131 \mu \mathrm{g} \mathrm{m}^{-3}$, respectively. Based on the year-long measurements over Guwahati, 

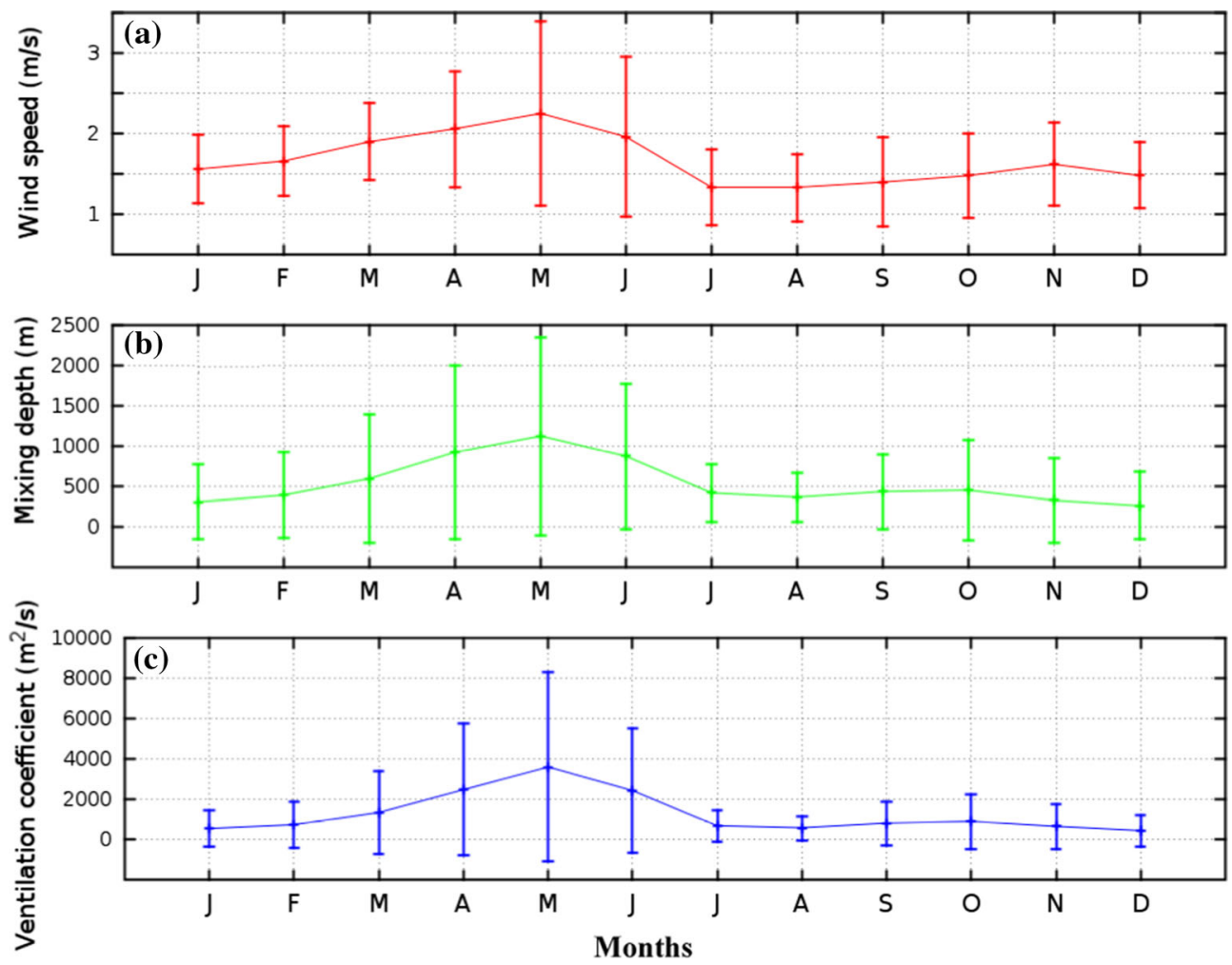

Figure 5. Average seasonal cycle (a) wind speed (b) mixing depth and (c) ventilation coefficient in Dehradun obtained from model fields (ECMWF ERA-interim-forecasts) for the study.

(a)

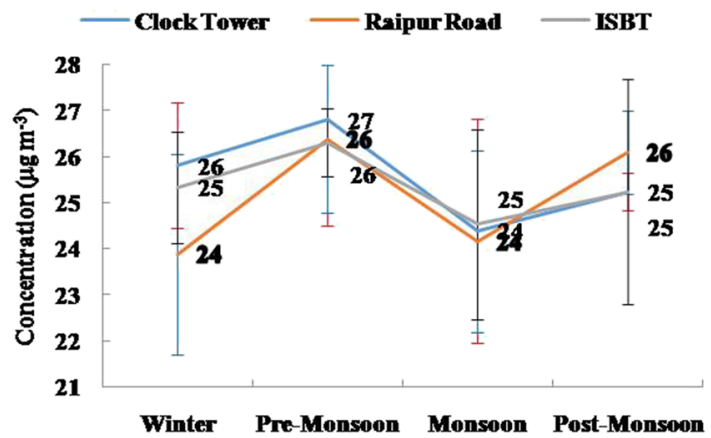

(c)

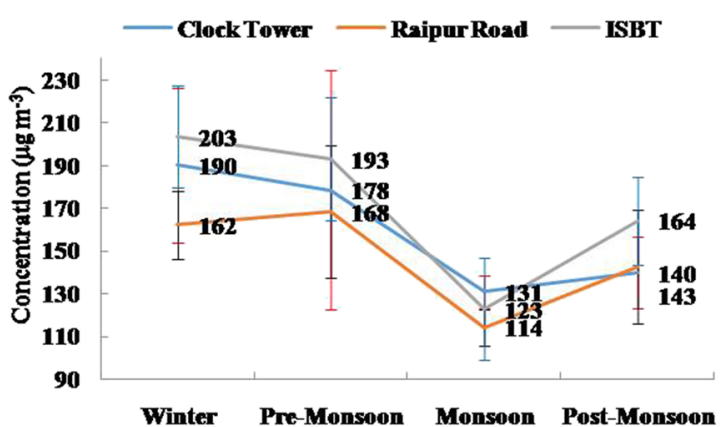

(b)

$\mathrm{NO}_{2}$

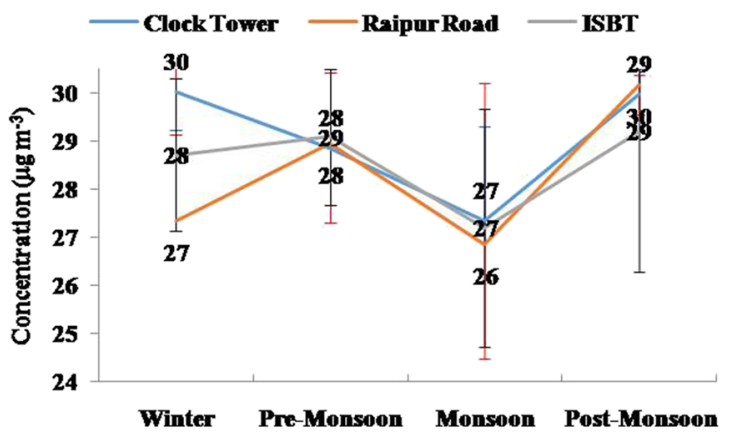

(d)

SPM

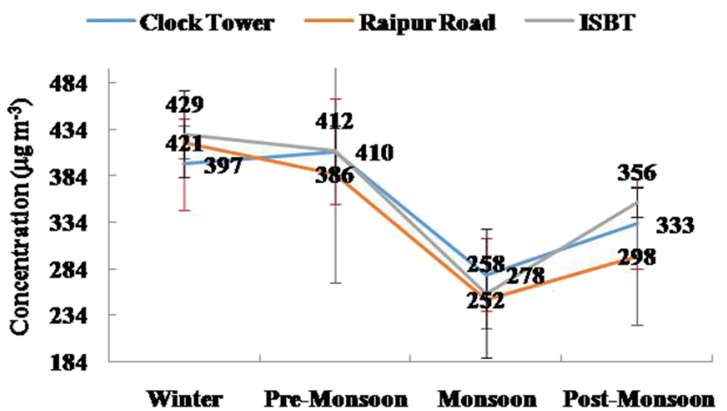

Seasons

Figure 6. Seasonal variations of air pollutants observation sites in Dehradun during 2011-2014 period. 
Tiwari et al. (2017) have also shown the high mass concentration of $\mathrm{PM}\left(\mathrm{PM}_{2.5}\right.$ and $\left.\mathrm{PM}_{10}\right)$ during the winter months.

Similarly, the maximum concentration of SPM was observed during winter in 2013 and 2014, while it was maximum during pre-monsoon in the year 2011 and 2012. In the year 2011, the highest seasonal average of $429 \mu \mathrm{g} \mathrm{m}^{-3}$ was recorded in the winter and lowest of $218 \mu \mathrm{g} \mathrm{m}^{-3}$ was in the monsoon. In the year 2012, maximum value of $463 \mu \mathrm{g} \mathrm{m}^{-3}$ was recorded in the pre-monsoon and a minimum of $276 \mu \mathrm{g} \mathrm{m}^{-3}$ in the monsoon.

Table 1. Annual statistics of pollutants in selected sites of Dehradun city in India during 2011-2014.

\begin{tabular}{|c|c|c|c|c|c|}
\hline Sites & Min & Max & Average & $\mathrm{SD}$ & $\mathrm{SE}$ \\
\hline \multicolumn{6}{|c|}{$\mathrm{PM}_{10}$ concentrations $\left(\mu \mathrm{g} \mathrm{m}^{-3}\right)$} \\
\hline CT & 78 & 310 & 162 & 49 & 7.4 \\
\hline $\mathrm{RR}$ & 67 & 283 & 144 & 37 & 5.5 \\
\hline ISBT & 70 & 303 & 167 & 50 & 7.5 \\
\hline \multicolumn{6}{|c|}{$\mathrm{SO}_{2}$ concentrations $\left(\mu \mathrm{g} \mathrm{m}^{-3}\right)$} \\
\hline $\mathrm{CT}$ & 16 & 31 & 25 & 2.5 & 0.3 \\
\hline $\mathrm{RR}$ & 18 & 28 & 24 & 2.3 & 0.3 \\
\hline ISBT & 19 & 28 & 24 & 2.1 & 0.3 \\
\hline \multicolumn{6}{|c|}{ SPM concentrations $\left(\mu \mathrm{g} \mathrm{m}^{-3}\right)$} \\
\hline $\mathrm{CT}$ & 129 & 1579 & 352 & 143 & 8.2 \\
\hline $\mathrm{RR}$ & 66 & 1603 & 334 & 142 & 9.4 \\
\hline ISBT & 94 & 1794 & 387 & 163 & 11.2 \\
\hline \multicolumn{6}{|c|}{$\mathrm{NO}_{2}$ concentrations $\left(\mu \mathrm{g} \mathrm{m}^{-3}\right)$} \\
\hline CT & 19 & 31 & 27 & 2.6 & 0.4 \\
\hline $\mathrm{RR}$ & 20 & 30 & 26 & 2.8 & 0.4 \\
\hline ISBT & 21 & 30 & 27 & 2.7 & 0.4 \\
\hline
\end{tabular}

In the year 2013 and 2014, the corresponding highest values were $408 \mu \mathrm{g} \mathrm{m}^{-3}$ for both years in the winter and lowest values observed were 237 and $316 \mu \mathrm{g} \mathrm{m}^{-3}$ in the monsoon, respectively.

The gaseous pollutant $\mathrm{SO}_{2}$ was found maximum $24 \mu \mathrm{g} \mathrm{m}^{-3}$ during pre-monsoon and minimum $20 \mu \mathrm{g} \mathrm{m}^{-3}$ in the post-monsoon in the year 2011. Similar trend was observed in the year 2012 with seasonal maximum and minimum are 26 and $24 \mu \mathrm{g} \mathrm{m}^{-3}$, respectively. But a slight change was observed in the trend in 2013, where highest seasonal average recorded was $25 \mathrm{\mu g} \mathrm{m}^{-3}$ in the premonsoon and the lowest recorded was $24 \mu \mathrm{g} \mathrm{m} \mathrm{m}^{-3}$ in the monsoon. Again in the year 2014, the highest seasonal average $26 \mu \mathrm{g} \mathrm{m}^{-3}$ was recorded in the pre-monsoon and lowest $25 \mu \mathrm{g} \mathrm{m}^{-3}$ during the post-monsoon. However, the other gaseous pollutant $\mathrm{NO}_{2}$ has shown somewhat different pattern. The maximum average of 26 and $28 \mu \mathrm{g} \mathrm{m}^{-3}$ was recorded in the year 2011 and 2013, respectively during winter, while it was maximum 27 and $29 \mu \mathrm{g} \mathrm{m}^{-3}$ in the year 2012 and 2014 in pre-monsoon season. On the other hand, minimum values were observed during monsoon season except in the year 2011. These values observed were

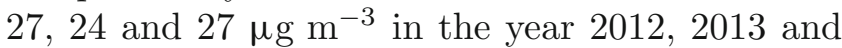
2014, respectively and $19 \mu \mathrm{g} \mathrm{m}^{-3}$ in the year 2011 . A comparison of the concentration of these pollutants with observation at different sites in India is given in table 2 .

The measured concentrations of $\mathrm{PM}_{10}$ and SPM were found relatively high at ISBT and CT as compared to $\mathrm{RR}$ due to the higher traffic emissions

Table 2. Comparison of air pollutants in different sites in India.

\begin{tabular}{|c|c|c|c|c|c|c|c|}
\hline \multicolumn{8}{|c|}{ Comparison of air pollutants of different sites $\left(\mu \mathrm{g} \mathrm{m}^{-3}\right)$} \\
\hline Sites & Years & Seasons & $\mathrm{SO}_{2}$ & $\mathrm{NO}_{2}$ & $\mathrm{PM}_{10}$ & SPM & References \\
\hline \multirow[t]{4}{*}{ Mizoram (Aizawl) } & \multirow[t]{4}{*}{$2012-2013$} & Winter & 4 & 22 & 217 & 260 & \multirow[t]{4}{*}{ Rai and Chutia (2014) } \\
\hline & & Pre-Monsoon & 5 & 23 & 225 & 272 & \\
\hline & & Monsoon & 1 & 10 & 59 & 100 & \\
\hline & & Post-Monsoon & & & & & \\
\hline \multirow{4}{*}{$\begin{array}{l}\text { Andhra Pradesh } \\
\text { (Visakhapatnam) }\end{array}$} & \multirow[t]{4}{*}{$2012-2013$} & Winter & 78 & 72 & 135 & & \multirow{4}{*}{$\begin{array}{l}\text { Srinivas and } \\
\text { Purushotham (2013) }\end{array}$} \\
\hline & & Pre-Monsoon & 41 & 48 & 169 & & \\
\hline & & Monsoon & 61 & 59 & 100 & & \\
\hline & & Post-Monsoon & 42 & 41 & 104 & & \\
\hline \multirow[t]{3}{*}{ Agra } & 2011 & & 3 & 6 & 282 & 360 & \multirow[t]{6}{*}{ Mishra et al. (2014) } \\
\hline & 2012 & & 5 & 8 & 275 & 405 & \\
\hline & 2013 & & 5 & 7 & 320 & 490 & \\
\hline \multirow[t]{3}{*}{ Dehradun (CT) } & 2011 & & 23 & 24 & 171 & 397 & \\
\hline & 2012 & & 26 & 28 & 177 & 368 & \\
\hline & 2013 & & 24 & 27 & 138 & 298 & \\
\hline
\end{tabular}


(a)

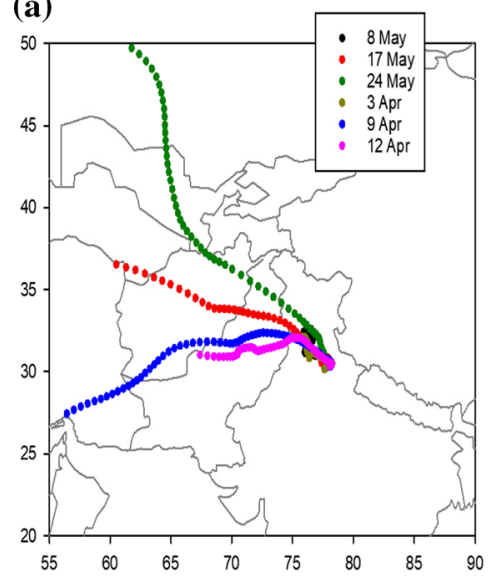

(b)

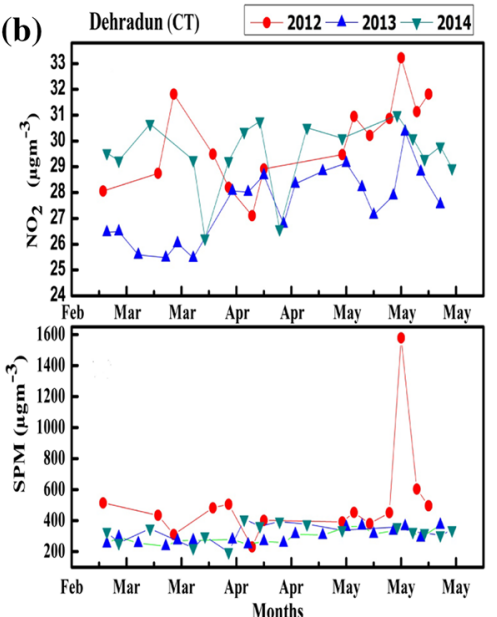

(c)

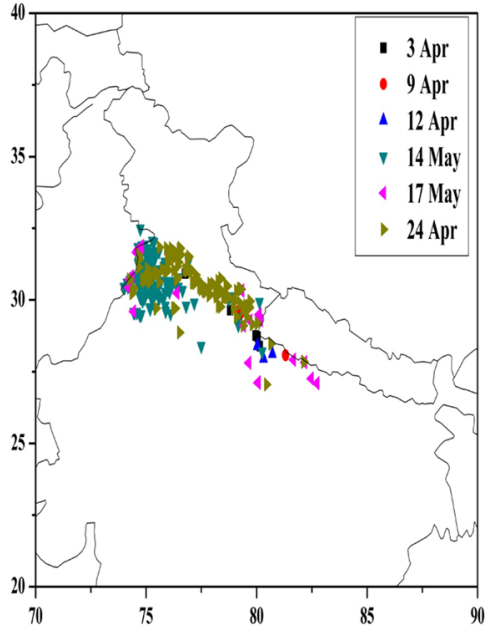

Figure 7. (a) Backward air trajectories ending at 06 UTC with $200 \mathrm{~m}$ (AGL), (b) times series of $\mathrm{NO}_{2}$, and $\mathrm{SO}_{2}$ and (c) location of fire during selected days in the northern India.

Table 3. Correlation coefficient between air pollutants and meteorological parameters using Pearson's product-moment method for (a) site CT, (b) site RR and (c) site ISBT.

\begin{tabular}{|c|c|c|c|c|c|c|c|}
\hline Parameters & $\mathrm{SO}_{2}$ & $\mathrm{NO}_{2}$ & RSPM & SPM & Temp & $\mathrm{RF}$ & WD \\
\hline \multicolumn{8}{|l|}{ (a) Site $C T$} \\
\hline $\mathrm{SO}_{2}$ & 1 & 0.79 & 0.51 & 0.56 & -0.13 & -0.32 & 0.25 \\
\hline $\mathrm{NO}_{2}$ & & 1.00 & 0.33 & 0.37 & -0.27 & -0.31 & 0.12 \\
\hline $\mathrm{PM}_{10}$ & & & 1.00 & 0.89 & -0.09 & -0.12 & 0.20 \\
\hline SPM & & & & 1.00 & -0.12 & -0.16 & 0.20 \\
\hline Temp. & & & & & 1.00 & 0.17 & 0.16 \\
\hline $\mathrm{RH}$ & & & & & & 0.31 & -0.41 \\
\hline $\mathrm{RF}$ & & & & & & 1.00 & -0.13 \\
\hline WD & & & & & & & 1.00 \\
\hline \multicolumn{8}{|l|}{ (b) Site $R R$} \\
\hline $\mathrm{SO}_{2}$ & 1.00 & 0.86 & 0.46 & 0.42 & 0.03 & -0.31 & 0.18 \\
\hline $\mathrm{NO}_{2}$ & & 1.00 & 0.36 & 0.37 & -0.09 & -0.32 & 0.11 \\
\hline $\mathrm{PM}_{10}$ & & & 1.00 & 0.73 & -0.09 & -0.17 & 0.10 \\
\hline SPM & & & & 1.00 & -0.10 & -0.18 & 0.22 \\
\hline Temp. & & & & & 1.00 & 0.14 & 0.20 \\
\hline $\mathrm{RF}$ & & & & & & 1.00 & -0.14 \\
\hline WD & & & & & & & 1.00 \\
\hline \multicolumn{8}{|l|}{ (c) Site ISBT } \\
\hline $\mathrm{SO}_{2}$ & 1.00 & 0.86 & 0.38 & 0.35 & 0.004 & -0.26 & 0.16 \\
\hline $\mathrm{NO}_{2}$ & & 1.00 & 0.34 & 0.35 & -0.15 & -0.27 & 0.08 \\
\hline $\mathrm{PM}_{10}$ & & & 1.00 & 0.61 & -0.11 & -0.18 & 0.02 \\
\hline SPM & & & & 1.00 & -0.06 & -0.22 & 0.20 \\
\hline Temp. & & & & & 1.00 & 0.20 & 0.31 \\
\hline $\mathrm{RF}$ & & & & & & 1.00 & -0.02 \\
\hline WD & & & & & & & 1.00 \\
\hline
\end{tabular}

in its vicinity. Burning of wooden logs and other camp fire activities around the roads for warming are an additional source during the winter. The traffic emissions and wood burning-clubs with the moisture form dense smog (Geddes and Murphy 2012). The Rajpur road has relatively lower concentrations of $\mathrm{PM}_{10}$ and SPM in all the seasons indicating lesser effects of local emissions and a forest cover.

The annual statistical variability of air pollutants over the three selected study sites is presented in table 1 . The statistical analysis includes different 

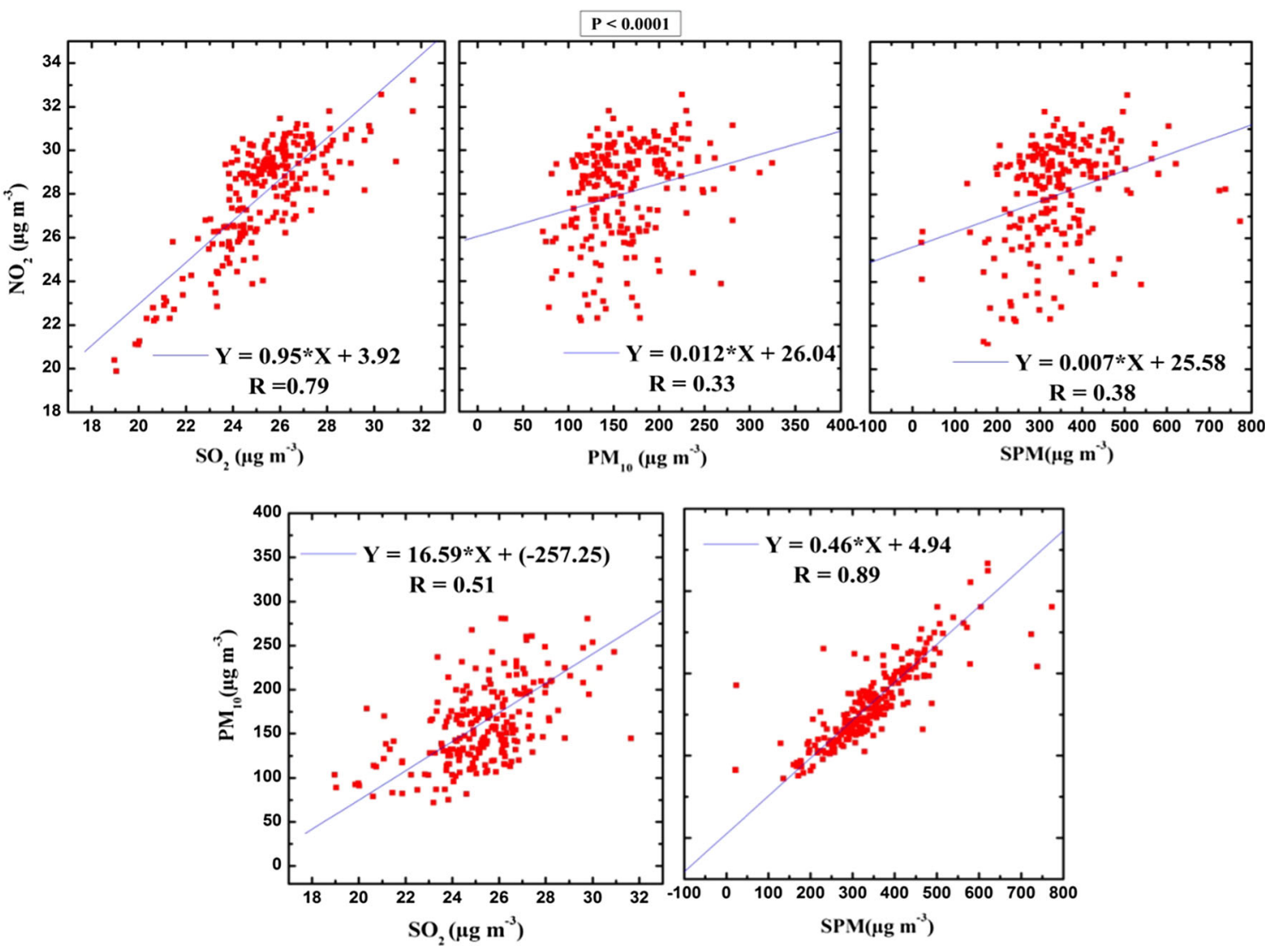

Figure 8. Linear regression $(Y=A X+B)$ of air pollutants at site CT.

values of pollutants (minimum, maximum and mean), standard deviation and standard error. The minimum, maximum and annual average concentration of $\mathrm{PM}_{10}$ was found to vary from 144 to $167 \mu \mathrm{g} \mathrm{m}^{-3}$ for all three sites. The minimum observed value of $\mathrm{PM}_{10}$ was found to be 133 $\mu \mathrm{g} \mathrm{m}^{-3}$ in the year 2013 and maximum value of $145 \mathrm{\mu g} \mathrm{m}^{-3}$ in the year 2014. The highest annual concentration of $\mathrm{PM}_{10}$ was recorded at ISBT in the year 2014 and lowest was recorded at RR in the year 2011. Similarly, the maximum and minimum annual average concentration of SPM was found to vary from 352 to $387 \mu \mathrm{g} \mathrm{m}^{-3}$ for all three sites.

The minimum value of SPM was observed in the year 2013 and maximum was observed in the year 2014. At ISBT, the highest annual concentration of $\mathrm{PM}_{10}$ was recorded in the year 2014 and lowest at RR in the year 2011. During the period 20112014, the maximum and minimum annual average concentrations of $\mathrm{SO}_{2}$ were found to vary from 21 to $25 \mu \mathrm{g} \mathrm{m}^{-3}$ for above sites.

\subsection{Back air trajectory analysis}

The highest values of particulate matter are observed on 17th May, 2012 over the study period
Table 4. AQI values and level of health concerns.

\begin{tabular}{lll}
\hline $\begin{array}{l}\text { Sl. } \\
\text { no. }\end{array}$ & AQI value & Level of health concern (AQI) \\
\hline 1 & $0-50$ & Good \\
2 & $50-100$ & Moderate \\
3 & $101-150$ & Unhealthy for sensitive group \\
4 & $151-200$ & Unhealthy \\
5 & $200-300$ & Very unhealthy \\
6 & $301-500$ & Hazardous \\
\hline
\end{tabular}

of 4 yrs. In order to understand the contribution from distant sources, a backward air mass trajectory analysis is carried out using HYSPLIT model (Stain et al. 2015). Figure 7(a) shows the air mass trajectory $200 \mathrm{~m}$ (AGL). It can be observed that most of the time on 17th May the air mass was from semi-arid dry regions in the west suggested to be transporting coarse mode particles above Dehradun. In general, during pre-monsoon the Himalayan foothills and adjacent plains encounter the episodes of enhanced dust (e.g., Kumar et al. 2014) contributing to higher levels of aerosols.

Northern Indian region experiences intense biomass burning every year during the pre-monsoon/ 
Table 5. AQI for all selected sites from 2011-2014 on yearly and monthly basis.

\begin{tabular}{|c|c|c|c|c|c|c|c|c|c|c|c|c|}
\hline \multirow{2}{*}{ Sites } & & & \multicolumn{10}{|c|}{ AQI on yearly basis } \\
\hline & & & \multicolumn{3}{|l|}{2011} & \multicolumn{3}{|l|}{2012} & \multicolumn{3}{|l|}{2013} & 2014 \\
\hline $\mathrm{CT}$ & & & \multicolumn{3}{|l|}{300} & \multicolumn{3}{|l|}{295} & \multicolumn{3}{|l|}{240} & 264 \\
\hline $\mathrm{RR}$ & & & \multicolumn{3}{|l|}{239} & \multicolumn{3}{|l|}{296} & \multicolumn{3}{|l|}{238} & 258 \\
\hline ISBT & & & \multicolumn{3}{|l|}{239} & \multicolumn{3}{|l|}{287} & \multicolumn{3}{|l|}{281} & 313 \\
\hline \multirow[b]{2}{*}{ Sites } & \multicolumn{12}{|c|}{ AQI on monthly basis } \\
\hline & Jan & Feb & Mar & Apr & May & Jun & Jul & Aug & Sep & Oct & Nov & Dec \\
\hline $\mathrm{CT}$ & 107 & 114 & 104 & 94 & 130 & 100 & 73 & 48 & 63 & 72 & 89 & 113 \\
\hline $\mathrm{RR}$ & 95 & 106 & 91 & 97 & 104 & 88 & 56 & 55 & 60 & 73 & 79 & 88 \\
\hline ISBT & 150 & 97 & 97 & 102 & 118 & 92 & 59 & 57 & 83 & 88 & 93 & 107 \\
\hline
\end{tabular}

spring as documented in previous studies (e.g., Kumar et al. 2011; Ojha et al. (2014)). The observations of fire location biomass burning (retrieved from MODIS; https://earthdata.nasa.gov/firms) are shown in figure $7(\mathrm{c})$. Effects of biomass burning could also be transported to the observation sites in Dehradun as shown in the air trajectories contributing to the elevated values during May (pre-monsoon).

\subsection{Correlation analysis}

The correlations between air pollutants and meteorological parameters are analyzed (table 3ac) using statistical methods Pearson's and Spearman's rank.

We observed that $\mathrm{SO}_{2}$ and $\mathrm{NO}_{2}$ show a good level of agreement, $(r=0.79)$, while the correlation between $\mathrm{SO}_{2}$ and $\mathrm{PM}_{10}$ was 0.51 , which is also a reasonably good positive correlation. The $\mathrm{SO}_{2}$ and SPM were also positively correlated $(0.57)$ in the CT area. Similar correlation was found between $\mathrm{NO}_{2}$ and $\mathrm{PM}_{10}$, which indicates that increase in one parameter is associated with increase in the other parameter. From table 3, it is clear that the meteorological parameters like temperature and rainfall show a negative correlation with air pollutants, while wind speed show a positive correlation with the above parameters. In the case of $\mathrm{PM}_{10}$ and SPM, a good positive correlation (0.89) was observed in the CT area. This may be due to the fact that in the city area motor vehicles, the large scale constructions and burning of garbage are the common sources of $\mathrm{SO}_{2}, \mathrm{NO}_{2}$ and particulate matter (ENVIS 2016). Clock tower being located in center of the city shows stronger anthropogenic influences, in particular due to heavy traffic causing simultaneous enhancements in the $\mathrm{PM}_{10}$ and SPM.
Figure 8 represents the linear regression analysis using the expression $Y=A X+B$, (here $Y$ is response variable, $X$ is predictor variable, the coefficient $A$ is the slope of regression line and $B$ is the intercept on the axis representing the concentration level of the response variable) for gaseous pollutant and particulate matter for all three selected sites. The high values of the $A$ and $B$ are for $\mathrm{NO}_{2}$ vs. $\mathrm{SO}_{2}$ at the site CT. However, for $\mathrm{SO}_{2}$ vs. $\mathrm{PM}_{10}$ and SPM, $A$ has negative values. In case of $\mathrm{PM}_{10}$ vs. SPM the values for $A$ and $B$ are positive and significantly high in all cases. Similarly, $\mathrm{PM}_{10}$ is also having a positive intercept with $\mathrm{NO}_{2}$ and $\mathrm{SO}_{2}$ and negative intercept with $\mathrm{SPM}$, indicating that the initial concentration of SPM relative to $\mathrm{PM}_{10}$ is relatively higher. Observed positive correlation indicate the common sources of observed pollutants especially emissions from traffic. In addition, the simultaneous enhancement in the $\mathrm{SO}_{2}$ and $\mathrm{NO}_{2}$ levels indicate the influences from energy generation plants.

\subsection{Air Quality Index}

The variation in the Air Quality Index (AQI) is useful for an overall assessment of possible health effects, as compared to that deduced from the individual pollutants (e.g., NAAQMS 2009; CPCB 2012) (table 4). AQI is computed as

$$
\mathrm{AQI}=\left(\frac{V_{\mathrm{o}}}{V_{\mathrm{s}}}\right) \times 100
$$

where $V_{\mathrm{o}}=$ observed values of air pollutants, $V_{\mathrm{s}}$ $=$ standard values recommended for the NAAQS (CPCB).

The values of the AQI calculated on yearly and monthly basis are presented in the table 5 . From the AQI values are found to be in the hazards and 
very unhealthy range as per the Environmental Protection Agency (EPA) guidelines. Additionally, at the ISBT station it also crossed the upper limit of the AQI of hazardous range. According to Sharma et al. (2017), in 2011, the scenario has changed somewhat with an increment in the number of vehicles, i.e., 154,666 plus local transport modes and the levels of all the pollutants have increased manifold. The results indicate that substantial growth in the population, traffic and energy needs has led to unhealthy conditions, especially near the major city centers/bus station. It is described to initiate more observation in the areas away from the major stations to further understand the dispersion of the enhanced pollution in Doon valley.

\section{Summary and conclusions}

This study analyzes the variability in the concentration of $\mathrm{SPM}, \mathrm{PM}_{10}, \mathrm{NO}_{2}$ and $\mathrm{SO}_{2}$ made at three sites in the Dehradun city, during 2011-2014 periods. Winter time elevated pollution is attributed to lower ventilation, as seen in the Era-Interim model fields and lack of precipitation.

The $\mathrm{PM}_{10}$ is found to vary between 150 and $195 \mu \mathrm{g} \mathrm{m}^{-3}$, whereas SPM between 350 and $470 \mu \mathrm{g} \mathrm{m}^{-3}$ during winter and summer. $\mathrm{PM}_{10}$ and SPM levels are found to be higher at ISBT and CT due to stronger traffic emissions in the vicinity and camp fire activities around the roads for warming during the winter. Inter-species correlations suggested influences from common sources on the air quality at observing sites, such as traffic emissions, large-scale constructions, and burning of garbage. Additionally, simultaneous enhancements in $\mathrm{SO}_{2}$ and $\mathrm{NO}_{2}$ might be due to the influences from energy production plants. Variations in the AQI indicate considerable degradation of the air quality in the Doon valley due to enhanced traffic and energy needs for growing population, especially near the bus station. More observations would be desirable to further understand the dispersion of elevated pollution from Dehradun city and the implications towards human health, vegetation and climate.

\section{Acknowledgements}

The authors would like to thank Dehradun Branches of Central Pollution Control Board and IMD for providing observation data used in this paper. One of the authors, AD is thankful to University Grants Commission (UGC) (Registration no.-14150), New Delhi, for the financial assistance under Campus Fellowship program for PhD. One of the authors NO acknowledges support and fruitful discussions with $\mathrm{H} \mathrm{N}$ Nagaraja and L M S Palni at Graphic Era, Dehradun. The authors would also like to thank ECMWF, Shinfield Park, Reading, UK for producing ERA-Interim dataset, NOAA Air Resources Laboratory for the provision of HYSPLIT transport and dispersion model and NASA Langley Research Center Atmospheric Science Data Center for providing the MODIS fire count data. The authors are highly grateful to the anonymous reviewers for their constructive comments, which helped substantially to improve the manuscript.

\section{References}

Akimoto H 2003 Global air quality and pollution; Science 302(5651) 1716-1719.

Aneja P V, Agarwal A, Roelle P A, Phillips S B, Tong Q, Watkins N and Yablonsk R 2001 Measurement and analysis of criteria pollutants in New Delhi, India; Environ. Int. 27(1) 35-42.

Awasthi S, Joshi P C, Pandey C P, Singh N and Nandan H 2016 Long term measurements of ambient air pollutants near a developing industrial township of district Haridwar, India; J. Am. Sci. 12(8) 85-91.

Butler T M, Lawrence M G, Gurger B R, van Aardenne J, Schultz M and Lelieveld J 2008 The representation of emissions from mega cities in global emission inventories; Atmos. Environ. 42(4) 703-719.

Chauhan A and Joshi P C 2008 Air quality index and its variation in Haridwar; J. Atmos. Biosci. 22(2) 171-176.

Chauhan A and Joshi P C 2010 Effect of ambient air pollutants on wheat and mustard crops growing in the vicinity of urban and industrial areas; New York Sci. J. 3(2) $52-60$.

Chauhan A, Pawar M, Kumar R and Joshi P C 2010 Ambient air quality status in Uttarakhand (India): A case study of Haridwar and Dehradun using air quality index; J. Am. Sci. 6(9) 565-574.

CPCB 2003 Parivesh: Polycyclic Aromatic Hydrocarbons (PAHs) in air and their effects of human health; Central Pollution Control Board, Ministry of Environment and Forest, New Delhi.

CPCB 2012 National ambient air quality status and 1350 trends-2012, August 2014, Central Pollution Control Board, Delhi-32, India.

CPCB 2015 Environmental data bank (CPCB), 1352, www.databank-cpcb.nic.in/.

Deep A, Chhavi P P, Nandan H and Purohit K 2017 Analysis of air pollutants in Rishikesh and Dehradun city of Uttarakhand: Influence of surface meteorological parameters; J. Environ. Biosci. 31(2) 459-462. 
Dumka U C, Darga S S, Kaskaoutis D G, Kant Y and Mitra D 2017 Columnar aerosol characteristics and radiative forcing over the Doon Valley in the Shivalik range of northwestern Himalayas; Environ. Sci. Poll. Res. 23 25,467-25,484, https://doi.org/10.1007/ s11356-016-7766-y.

ENVIS 2016 Newsletter on urban ambient air quality status in Uttarakhand.

Geddes J A and Murphy J G 2012 The science of smog: A chemical understanding of ground level ozone and fine particulate matter; In: Metropolitan Sustainability, Woodhead Publishing, pp. 205-230.

Gurjar B R, Butler T M, Lawrence M G and Lelieveld J 2008 Evaluation of emissions and air quality in mega cities; Atmos. Environ. 42(7) 1593-1606.

Gurjar B R, Ravindra K and Nagpure A S 2016 Air pollution trends over Indian megacities and their local to-global implication; Atmos. Environ. 142 475495.

Gurjar B R, Jain A, Sharma A, Agarwal A, Gupta P, Nagpure A S and Lelieveld J 2010 Human health risks in megacities due to air pollution; Atmos. Environ. 44(36) 4606-4613.

IMD 2015 India Meteorological Department Annual Report; Ministry of Earth Science, Government of India.

Jacobs M and Hochheiser S 1958 Continuous sampling and ultramicro determination of nitrogen dioxide in air; Anal. Chem. 30(3) 426-428.

Kanakidou M, Mihalopoulos N, Kindap T, Im U, Vrekoussis M, Gerasopoulos E, Dermitzaki E, Unal A, Koçak M, Markakis K and Melas D 2011 Megacities as hot spots of air pollution in the East Mediterranean; Atmos. Environ. 45(6) 1223-1235.

Krass F 2007 Megacities and global change: Key priorities; Geog. J. 173(1) 79-82.

Kumar R, Naja M, Satheesh S K, Ojha N, Joshi H, Sarangi T, Pant P, Dumka U C, Hegde P and Venkataramani S 2011 Influences of the springtime northern Indian biomass burning over the central Himalayas; J. Geophys. Res.: Atmos. 116(D19).

Kumar R, Barth M C, Madronich S, Naja M, Carmichael G. R, Pfister G G, Knote C, Brasseur G P, Ojha N and Sarangi T 2014 Effects of dust aerosols on tropospheric chemistry during a typical pre-monsoon season dust storm in northern India; Atmos. Chem. Phys. 14 6813-6834; https://doi.org/10.5194/acp-14-6813-2014.

Mishra A K, Klingmueller K, Fredj E, Lelieveld J, Rudich $\mathrm{Y}$ and Koren I 2014 Radiative signature of absorbing aerosol over the eastern Mediterranean basin; Atmos. Chem. Phys. 14(14) 7213-7231.

Molina M J and Molina L T 2004 Megacities and atmospheric pollution; J. Air Waste Manag. Assoc. 54(6) 644-680.

NAAQMS 2009-2010 National ambient air quality monitoring series; Central Pollution Control Board, Ministry of Environment and Forest.

Ojha N, Naja M, Singh K P, Sarangi T, Kumar R, Lal S, Lawrence M G, Butler T M and Chandola H C 2012 Variabilities in ozone at a semi-urban site in the IndoGangetic Plain region: Association with the meteorology and regional Processes; J. Geophys. Res. 117 D20301, https://doi.org/10.1029/2012JD017716.
Ojha N, Naja M, Sarangi T, Kumar R, Bhardwaj P, Lal S, Venkataramani S, Sagar R, Kumar A and Chandola H C 2014 On the processes influencing the vertical distribution of ozone over the central Himalayas: Analysis of yearlong ozonesonde observations; Atmos. Environ. 88 201211.

Ojha N, Pozzer A, Akritidis D and Lelieveld J 2017 Secondary ozone peaks in the troposphere over the Himalayas; Atmos. Chem. Phys. 17 6743-6757, https:// doi.org/10.5194/acp-17-6743-2017.

Rai P K and Chutia B M 2014 Assessment of ambient air quality status before and after shifting cultivation in an Indo-Burma hotspot region; Int. Res. J. Environ. Sci. 3(11) 1-5.

Ramanathan V and Feng Y 2009 Air pollution, greenhouse gases and climate change: Global and regional perspectives; Atmos. Environ. 43 37-50.

Ravindra K, Sindu M K, Mor S, John S and Pyne S 2016 Air pollution in India: Bridging the gap between science and policy; J. Hazard Toxic Radioact. Waste 20(4) A4015003.

Sarangi T, Manish N, Ojha N, Kumar R, Lal S, Venkataramani S, Kumar A, Sagar R and Chandola H C 2014 First simulation measurement of ozone, $\mathrm{CO}$, and $\mathrm{NO}_{y}$ at a high-altitude regional representative site in the central Himalayas; J. Geophys. Res. Atmos. 119 1592-1611, https://doi.org/10.1002/2013JD020631.

Sharma M, Pal B, Pal A and Bajpai A B 2017 Spatiotemporal changes and impact of air pollution on human health: A case study of Dehradun city; Int. J. Environ. Reh. Cons. 8 1-10.

Sokhi R S and Kitwiroon N 2008 Air pollution in urban areas; In: World Atlas of Atmospheric Pollution (ed.) Sokhi R S, Anthem Press, London, UK.

Solanki R, Singh N, Pant P, Dumka U C, Kumar Y B, Srivastava A K, Bisht S and Chandola H C 2013 Detection of long range transport of aerosols with elevated layers over high altitude station in the central Himalayas: A case study on 22 and 24 March 2012 at ARIES, Nainital; Indian J. Radio Space Phys. 42 $232-239$.

Srinivas J and Purushotham A V 2013 Determination of air quality index status in industrial areas of Visakhapatnam, India; Res. J. Eng. Sci. 2(6) 13-24.

Srivastava A K, Soni V K, Singh S, Kanawade V P, Singh N, Tiwari S and Attri S D 2014 An early South Asian dust storm during March 2012 and its impacts on Indian Himalayan foothills: A case study; Sci. Total Environ. 493 526-534.

Stain A F, Draxler R R, Rolph G D, Stunder B J B, Cohen M D and Ngan F 2015 NOAA's HYSPLIT atmospheric transport and dispersion modeling system; Bull. Am. Meteor. Soc. 96 2059-2077, https://doi.org/10.1175/ BAMS-D-14-00110.1.

Tiwari S, Dumka U C, Gautam A S, Kaskaoutis D G, Srivastava A K, Bisht D S, Chakrabarty R K, Sumlin B $\mathrm{J}$ and Solmon F 2017 Assessment of $\mathrm{PM}_{2.5}$ and $\mathrm{PM}_{10}$ over Guwahati in Brahmaputra River Valley: Temporal evolution, source apportionment and meteorological, dependence; Atmos. Pollut. Res. 8 13-28.

UN-Habitat 2012 State of the World's Cities 2008/9; Harmonious Cities, Routledge. 
Wenzel F, Bendimerad F and Sinha R 2007 Megacities mega risks; Nat. Hazards 4 481-491, https://doi.org/10. 1007/s11069-006-9073-2.
West P W and Gaeke G C 1956 Fixation of sulphur dioxide as sulfitomercurat (II) I and subsequent colorimetric determination; J. Anal. Chem. 28 1816-1819.

Corresponding editor: Suresh BABU 